\title{
Cultural Intelligence and Gainful Employment in Management
}

\author{
Dr. Soni Kewalramani ${ }^{1 *}$, Shruti Chaubey ${ }^{2}$
}

\section{ABSTRACT}

Globalization requires dissolution of cultural boundaries to result inter mixing of cultures; this demand gives the need a leader who is culturally sensitive and can understand others culture as well. In other words the leader with the high cultural intelligence (CQ) is needed. The second variable under study in the present research is Gainful Employment. Gainful employment is employment condition where the employee gets consistent payment, appraisal and work from the employer. The present study was carried out to find out the relationship between the CQ and Gainful employment. The researcher has collected data of 80 sample in which 40 were from Government sector and 40 from private sector. Research also wanted to find out that who is more culturally intelligent and gainfully employed; government employees or private sector employees because working condition and type of work are totally different in there two sectors. This result shows that Private sector employees have high CQ in comparison to government sector employees. Private sector employees cores high on all 4 domains of CQ that is CQ strategy, CQ knowledge, CQ motivation and CQ behaviour, also results shows that private sector employees are more gainfully employees or perceive themselves ore gainfully employed in comparison to government employees.

Keywords: Cultural, Intelligence, Gainful, Employment, Management

Management is defined as the art of getting things done through people. Management involves overseeing and coordinating the work of others, so that their activities are completed effectively and efficiently.

In the modern era of globalization industries do not want to remain indigenous. Different organizations are thriving to be global and execute their business in different countries and some of them are succeeding in their pursuit. This involves dissolution of cultural boundaries to result inter mixing of cultures; this demand gives the need a leader who is culturally sensitive and can understand others culture as well. In other words the leader with the high cultural intelligence

\footnotetext{
${ }^{1}$ Assistant Professor, Amity University Uttar Pradesh, Lucknow Campus, Lucknow, India

${ }^{2}$ Research Scholar, Amity University Uttar Pradesh, Lucknow Campus, Lucknow, India

*Responding Author
}

Received: February 6, 2017; Revision Received: March 7, 2017; Accepted: March 10, 2017

(C) 2017 Kewalramani S, Chaubey S; licensee IJIP. This is an Open Access Research distributed under the terms of the Creative Commons Attribution License (www.creativecommons.org/licenses/by/2.0), which permits unrestricted use, distribution, and reproduction in any Medium, provided the original work is properly cited. 


\section{Cultural Intelligence and Gainful Employment in Management}

(CQ) is needed.

Employees can only be able to deal with diversity only when they feel happy and satisfied with their job. Also when they enjoy different varieties in their job and feel safe in their work place. In today's world with increasing pressure and competition, employees don't enjoy their work. They feel suffocated and not able to perform and achieve their goals. To develop a manager or an employee who is culturally intelligent. It is important to identify that employees consider themselves gainfully employed or not. When an individual is satisfied with his job then only he can take that extra effort to understand diversity and tries to learn deal effectively with it.

Cultural intelligence as described by the (Ang, Dyne 2005; Earley \& Ang, 2003, Mosakowski, and Earley 2005) "is a person's capability to function effectively in situations that is characterized by cultural diversity. CQ is the critical capability that enhances manager, employees and organizational effectiveness. It also helps in enhancing of interpersonal interactions in a wide range of social contexts.' The term and the concept of the cultural intelligence were first used by the Ang and Earley. In their first book "cultural intelligence: interactions across culture."

The frame work of the Cultural intelligence is based on the Detterman's \& Sternberg (1986) integration of the different loci of intelligence that is residing within the individual. Applying Sternberg's theory of multiple loci of intelligence, Ang and Earley (2003) conceptualized Cultural intelligence in four dimensions which comprises of metacognitive CQ (Strategy CQ), motivational CQ (knowledge CQ), cognitive CQ and behavioural CQ with specific importance to functioning in cross cultural settings.

Meta cognitive CQ also known as strategy CQ reflects the ability of the individual's mental processes that he uses to acquire and understand cultural knowledge, which includes the knowledge and control over the individual thought processes that are relating to different culture.

Individuals with the high Strategy CQ or meta cognitive CQ are conscious of others' cultural preferences not only during the interactions but also before the interaction. They not only tries to understand others cultural preferences but also tries to question cultural assumptions and are able to adjust their mental model after and during the interactions.

Cognitive CQ also referred as Knowledge CQ reflects the individual's knowledge of set of rules, practices, and their conventions in different cultures, which they acquired from personal experiences and education. This knowledge includes knowledge of legal differences, interpersonal ability and sociolinguistic systems of different cultures and various subcultures and also this includes the ability to understand the basic of frameworks of cultural values. People with high knowledge CQ understand similarities and the differences across cultures.

(c) The International Journal of Indian Psychology, ISSN 2348-5396 (e) | ISSN: 2349-3429 (p) | 105 


\section{Cultural Intelligence and Gainful Employment in Management}

Motivational CQ the third dimension of cultural intelligence is the capability of the individual to direct energy and attention toward learning about the functioning in situations that are characterized by cultural diversity. Individual those are with high motivational CQ direct their attention and potential toward culturally different situations.

Behavioral CQ the fourth dimension of cultural intelligence is the ability to reflect the individual's ability to use appropriate verbal and nonverbal actions when he or she is interacting with client from different cultures. Individual those are with high behavioral CQ shows behaviours appropriate to the situations based on their wide range of verbal and nonverbal capabilities, like the use of culturally appropriate words, tone, gesture and facial expressions.

\section{Benefits of CQ}

If the individual is culturally intelligent then it not only helps him in his professional life but develop his overall personality. If the individual is culturally intelligent they he or she enjoys many benefits.

1. When the individual is high on any one dimension of CQ then it gives him the insight that helps him to capitalize his strengths.

2. If the individual is high on CQ then it can also help him to become more knowledgeable, strategic, flexible and motivated.

3. It enhances the culturally sensitivity of the individual

4. It helps in the reducing the use of stereotypes.

5. It also improves the work performance, decision making and judgement of the individual.

6. It also helps the individual to understand his or her strengths and weaknesses.

7. It also helps the individual to understand the others culture and there sociolinguistic system.

8. The major benefit of understanding CQ that it helps in self development.

9. People with high CQ are also able to understand cultural norms and practices of others which help them to deal with diversity effectively.

10. People with high CQ are also able to understands the differences and the similarities across cultures and able to deal with the differences.

11. The individual with high CQ are also able to act appropriately according to the situations. As the aim of the present study is to find out the relationship between the CQ and Gainful employment it is important to get the better understanding of gainful employment.

\section{Gainful employment}

Gainful employment as its name implies is employment condition where the employee gets consistent payment, appraisal and work from the employer. Gainful employment emerged from the positive psychology and it focuses on the benefits of work and employment. Gainful employment can be characterized by the following nine benefits: 


\section{Cultural Intelligence and Gainful Employment in Management}

1. Variety in duties -if the employee is always given the same type of work, and there is no variety. The productivity of the employee will decrease and he will feel bored.

2. Safe working condition and environment - Safe working environment and condition increase not only the productivity but also helps the employee to enjoy his work.

3. Income for oneself and for loved ones -income is very important for the job satisfaction but high income does not always mean that employee is gainfully employed.

4. Purpose derived from providing a service or product - employee can derive purpose in his life from the task that he completes.

5 Satisfaction and happiness - for the satisfaction and happiness in the work there must be a balance and similarity between the individual's activities and his or her knowledge, attitudes and skills.

6. Positive involvement and engagement - individual must have the sufficient amount of task to perform and complete and have the knowledge and all the resources to complete the task.

7. Sense of performing well and meeting desired goals - employee must believe that he or she is capable of performing at work and achieving the goals that he set.

8. Friendships at work place - Healthy companionship between the employees have been proven to cause to lesser accidents, more engaged clients, increased productivity, increased achievement and increased job satisfaction.

9. An environment that understands and appreciates diversity -in today's work place the ethnic and racial diversity are increasing rapidly. Manager should try to use the diversity management techniques to handle the increased diversity.

(c) The International Journal of Indian Psychology, ISSN 2348-5396 (e) | ISSN: 2349-3429 (p) | 107 


\section{Cultural Intelligence and Gainful Employment in Management}

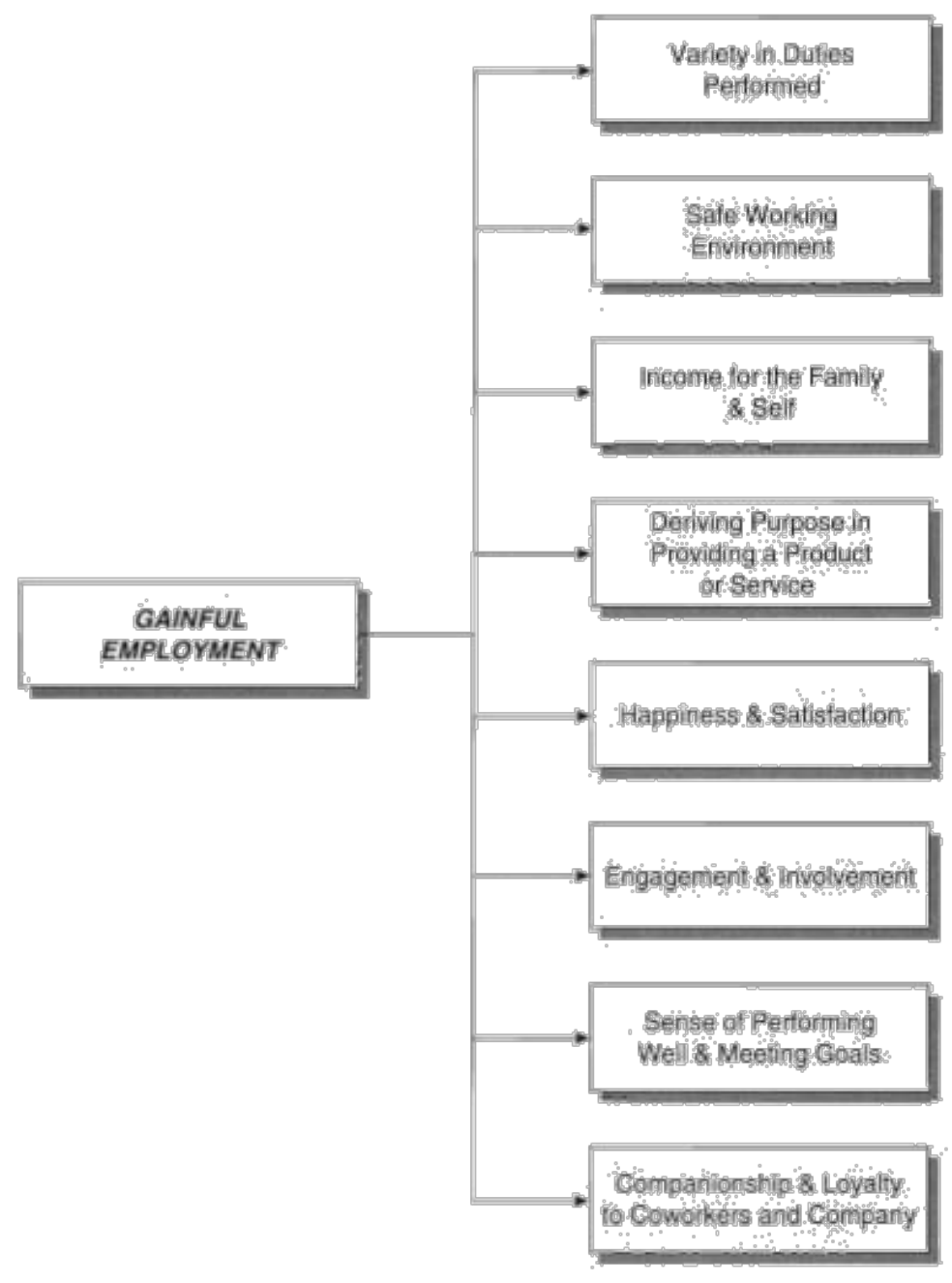

Figure 1: Nine characteristic of gainful employment (Source: Snyder \& Lopez 2007)

Gainful employment is all about perception. One cannot be gainfully employed until and unless he or she perceived that he is gain fully employed. There are certain factors in the job which makes the employee to perceive that he is a gainfully employed.

\section{Satisfaction and happiness}

If the employee is happy at work, chances are that his or her overall satisfaction of life will be higher. It is often observed that an employed person consistently seems happier in comparison to that of unemployed people.

\section{Performing and meetings goals}

Performing well at task is more likely to occur when workers have clear and desirable goals. Lucid goals offer satisfaction when they are met, accordingly when work goals are clearly

(c) The International Journal of Indian Psychology, ISSN 2348-5396 (e)| ISSN: 2349-3429 (p) | 108 


\section{Cultural Intelligence and Gainful Employment in Management}

described and employees can meet established standards, heightened personal pleasure and a sense of accomplishment result. In this regard, the high-hope leader's clear goal setting and facile communication provide lucid short- and long-term objectives for the work group. A high-hope boss also can provide greater satisfaction at work. This sequence unfolds this way: the high-hope boss clearly identifies achievable work sub goals; which in turn increases workers' motivation and the chances of reaching larger, organizational goals. In this process, the hopeful leader also facilitates workers' willingness to embrace the company's overall objectives.

\section{Purpose derived from providing a service or product}

Ones work also is very important potential source of purpose in life. A major underlying force that drives such purpose is the sense of providing needed products or services to customers. Workers want, sometimes in very small ways, to feel that they are making a contribution to other people and to their society.

\section{Engagement and involvement}

Engagement is the employee's involvement with his or her work, whereas satisfaction is what we might call employee enthusiasm at work. Engagement is said to occur when employees find that their needs are being met. specifically, engagement reflects those circumstances in which employees "know what is expected of them, have what they need to do their work, have opportunities to feel something significant with co -workers whom they trust, and have chances to improve and develop" similarly Warr (1998) has reported that the most engaging jobs are those with special duties and in which there is a good match between the required activities and the skills and personality of the employees. Engaged involvement at work bears a resemblance to the concept of flow, which entails any circumstances in which a person's skills facilitate success at challenging tasks.

\section{Variety in job duties}

If the tasks performed at work are sufficiently different then satisfactions come more easily. Indeed, boredom at work can cast a pall. People should maintain as much variety and stimulation as possible in their work activities. One fairly common practice for maintaining variety in workers' duties in industrial and technological job settings is cell manufacturing. In cell manufacturing, groups of multi-skilled workers take responsibility for an entire sequence in the production process. These work teams then put their identifying insignia on the product or portion of the product. Cell manufacturing has been used with some success in the construction of automobiles by work teams. (There have been concerns about this approach costing more, however, which has lessened its popularity among some companies). Lacking variability in work, the employee may lapse into what recently has been called presenteeism (in contrast to absenteeism). In presenteeism, the employee may physically be at work, but because of the mental health problems that often result from aversive and repetitive work experiences; he or she is unproductive and unhappy. Faced with repetitious and tedious tasks and inflexible schedules, 


\section{Cultural Intelligence and Gainful Employment in Management}

employees can become demoralized and lose their motivation. When seeking a new job, it may be advisable to take a position that offers great variety but lower pay instead of a higher-paying position that involves unchangeable, repetitive activities. Thus, the old maxim, "variety is the spice of life," is nowhere more applicable than in work settings.

\section{Income for family and self}

Without question, a minimum income is necessary to provide for the needs of one's family and oneself. Money is overrated as a source of happiness. indeed, two survey studies show that people seem to understand that happiness and meaning in life are not related in any major degree to the amount of money they make whether this "rational" approach to monetary rewards and work is actually practiced, however, remains questionable for example, making money has been rated as more important than having a cohesive philosophy of life. Though interpersonal relationships have been valued above work .Americans still may think quality of life in terms of how much money they make. The present generation of American workers is spending more time on the job than their parents did. In many two partner relationships, for example, both people have jobs and when making important life decisions, people are most likely to cite financial reasons. It seems as if we are of two minds about acquiring monetary wealth, and this ambivalence is played out in our work.

\section{Companionship and loyalty to co-workers and bosses: friends at work}

Work offers people a chance to get out of the house and interact with other people. Because workers may share experiences, including obstacles and triumphs in the work setting, there are reasons for people to form bonds with each other. Friendship in the work place also increases the productivity and job satisfaction.

\section{Safe work environments}

Part of happiness at work is a safe and healthy physical environment where it is obvious that management cares about the welfare of workers. If the employee feels safe in his or her work place the productivity and the job satisfaction will increase.

\section{REVIEW OF LITERATURE}

Review of literature suggests that many studies have been conducted in the area of cultural intelligence (CQ) and the gainful employment. The present chapter is divided into two sections. Section A which will discuss the researchers conducted for the cultural intelligence and the section B will deal with the researchers conducted for the gainful employment.

\section{Section A 1. Studies on the Effect of Personality on the CQ}

Ang el al (2006,) conducted the study on a large sample and found out that four dimensions of CQ were related yet distinct to big five factor theory. Black (2006) concluded in his study that experiential learning begins with a concrete experiences, but it also differ from individual to 


\section{Cultural Intelligence and Gainful Employment in Management}

individual. Templer el al (2006), conducted a study to examine the motivational CQ and found out that it predicts adjustment of global professionals. Van Velsor and colleagues (2004) found out in their study that other relevant characteristic including cognitive, self-esteem and selfefficacy affect the cultural intelligence of the individual. Ernest \& Daston (2004) observed in their study that both the learning abilities and personality traits influence the learning opportunity during overseas adjustment. Bandura (2002) reported that individual with the self-efficacy and desire deal with the challenging cross cultural situation more effectively. Spreitzer and colleagues (1997), found out in their study that ability to learn including taking a proactive approach to learning, adapting to change in the environment, learning from mistakes.

\section{Studies on the leadership and the $C Q$}

Van Dyne \& Ang (2006) found out in their research that difference in global leader initiative to span structural holes as key characteristics that differentiates there with high performance and positive reputation. Osland \& Osland (2006) conducted a study that expatriates who are more involved in the host culture are more likly to encounter paradoxes. Stahl and colleagues (2005) argued that individual are different in their involvement and hence the quality and amount of cultural experience they have.

Hall, Zhu and Yan (2004),argued that international assignment are a powerful means of developing leadership as it provides the opportunity for leader to experience surprise. Carpentz \& Sanders (2001) observed in their study that the international experience of CEOs was related to corporate finanicial performance of international farms. Osland\& Bird (2000) found that metacognition is directly relevant to abstract conceptualization because many cross cultural situations do not fit typical or norms even when expectance based on the scientific research.

Carpenter, Gregersen, (2001), Certo, Daily, \& Dalton, (2000), Sambharya, (1996,) found out in their study that firms led by CEOs with international experience perform better financially. Mendenhall \&oddou (1988) found out that expatriates indicate benefits of overseas assignment for their leadership capabilities. Gregersen, Morrison and Black (1998) conducted the study and found out that the living and working aboard was the most powerful experience in developing global leadership capabilities.

Above researches shows that cultural intelligence is influenced by many aspects like personality of the individual. Also it shows that cultural intelligence influence many traits like leadership and negotiation ability. It is also observed in above researches that cultural intelligence increased with experiences.

\section{Section $B$}

Present section deals with the researchers conducted for the gainful employment and its nine characteristic. 


\section{Cultural Intelligence and Gainful Employment in Management}

Pitts (2006) conducted the study and in which result showed that proper use of diversity management was predictive of better group performance in the workplace and higher level of job satisfaction for all the employees. Which is one of the characters of gainful employment?

Cunningham (2009) observed in his study that the relationship was better in athletic department that used proactive diversity management strategies which increase the friendship at work place and make employee feel gainfully employed. Herrbach (2006) found that individual who experienced more positive affect at work are more likely to experience higher level of affective commitment and make employee feel more gainfully employed.

Boehm \& Lyubomirsy (2005) found out in their study that the good work performance leads to the happier life and also increase satisfaction in work place. That make employee feel gainfully employed. Caspi \& Moffitt( 2003) found out that individuals who scored higher on well being measures in late adolescence will more positive outcomes in early adulthood. Argyler\& war 2001 found that employed people consistently report being happier than their counterparts without jobs.

Harter (2002) argues that engagement reflects those circumstances in which employee know, what is expected of them and have chance to improve and develop. Judge, Bono \& Patton (2001) performed a meta-analysis study and found out a reliable relationship between the performance and general satisfaction. Synder (2000) conducted a study and found out that performance of the employees increased when they have clear goals. Diener\& Lucas (1999) found out that the correlation of job satisfaction with overall happiness is about .40. Hart \& judge (1999) found out that if the person is satisfied with his job his or her overall satisfaction will be higher.

Cropanzano \& Wright (1999) argues that happy people are often regarded as stronger performer by others in the workplace. Schor (1991) found out that the present generation of the workers in United Nations is spreading more time on their job than their parents did because they have varities in their job and get better work environment. Mahan, Garrrd \& Lewsi (2002) found that the sense of commitment at the given workplace is a contributing factor to happiness and satisfaction. Which is one of the prime characteristic of gainful employment?

Rath (2006) conducted the study on the effect of friendship on the happiness, satisfaction and productivity of the employees. She observed that the productivity and the job satisfaction increased if the employees have good relationship with the colleagues, this also increase the safety which ultimately leads to make employee feel gainfully employed.

All the above research shows that gainful employment is about perception. Employee cannot be gainfully employed until and unless he feels it. Also studies show that there are many characteristic are responsible for making employee feel gainfully employed. 


\section{Cultural Intelligence and Gainful Employment in Management}

\section{METHODOLOGY}

The present research is carried out to find out the relationship between the Cultural intelligence and Gainful employment. Present study also tries to find out who is high on CQ and more gainfully employed Private sector employees or government sector employees.

\section{Objective}

1. To find out who is high on CQ government employees or private sector employees. To find out who is more gainfully employed government employees or private sector employees.

2. To find out the relationship between the cultural intelligence and gainful employment.

\section{Research design}

The ex post facto and correlational research design was adopted due to the nature of the study. Ex post facto study or after-the-fact research is a category of research design in which the investigation starts after the fact has occurred without interference from the researcher. The majority of social research, in contexts in which it is not possible or acceptable to manipulate the characteristics of human participants, is based on ex post facto research designs. It is also often applied as a substitute for true experimental research to test hypotheses about cause-and-effect relationships or in situations in which it is not practical or ethically acceptable to apply the full protocol of a true experimental design.

Correlational Research is also known as Associational Research. Relationships among two or more variables are studied without any attempt to influence them. It also helps in Investigating the possibility of relationships between two variables. There is no manipulation of variables in Correlational Research.

\section{Variables}

1. Cultural intelligence (CQ) is a person's capability to function effectively in situations that is characterized by cultural diversity. CQ is the critical capability that enhances manager, employees and organizational effectiveness. It also helps in enhancing of interpersonal interactions in a wide range of social contexts.

2. Gainful employment as its name implies is employment condition where the employee gets consistent payment, appraisal and work from the employer. Gainful employment emerged from the positive psychology and it focuses on the benefits of work and employment.

\section{Sample}

80 employees from different organization in Lucknow were selected. The 40 employees were from government sector and 40 from private sector. Purposive sampling technique was used for data collection. 


\section{Cultural Intelligence and Gainful Employment in Management}

Purposive sampling is a form of non-probability sampling in which decisions concerning the individuals to be included in the sample are taken by the researcher, based upon a variety of criteria which may include specialist knowledge of the research issue, or capacity and willingness to participate in the research.

\section{Measures (tools)}

Cultural intelligence: Cultural intelligence was measured with the 20-item, self-reported Four Factor Model of Cultural Intelligence Scale (CQS) developed and validated by Ang et al. (2007). The inventory includes four items for meta-cognitive CQ $(\alpha=.76)$, six for cognitive CQ $(\alpha=.84)$, five for motivational CQ $(\alpha=.76)$, and five for behavioral CQ $(\alpha=.83)$. Respondents are asked to use a seven-point Likert-type scale to indicate the extent to which each item describes their capabilities. The seven-point Likert-type scale ranges from strongly disagree (1) to strongly agree (7).

Gainful employment: Gainful Employment Measure (Snyder and Lopez, 2007) scale was used to asses that whether the employee is gainfully employed or not. Respondent were asked to rate the 9 components of gainful employment out of 4 which will show the extent to which they are satisfied with their job.

The tools used in the present study are culture free and was also tested by the researcher with the help of experts. Researcher also used these tools in her pilot study with similar type of data of 10 samples which is not used in the present study also shows that tools are culture free .

\section{Method of data collection}

The study aimed at employees working in government sector and private sector in Lucknow India. For the data collection two organizations were selected. The employees of managerial level were selected 40 from government sector and 40 from private sector. Each of the participants was given two questionnaires. It was make sure that participant have answered all the questions. It was also made sure that all participants were literate in English language and understood all the instructions given to them.

\section{Data processing}

Statistical Package for the Social Sciences (SPSS) version 20.0 was religiously used for the statistical analyses. Coding of variables in quantitative research is very critical for better interpretation of results. Age, designation, sub scores and final scores were all coded and were entered in to the computer. The questions and responses were coded and entered in the computer using Microsoft Excel software. Required analysis was done with the aid of Statistical Package for Social Sciences 20.0 Version. The data gathered by the questionnaire was analyzed by the use of descriptive statistics and correlations analyses. 


\section{Cultural Intelligence and Gainful Employment in Management}

\section{RESULTS AND DISCUSSION}

When the organizations are more varied culturally, they need more individuals with multinational skills and knowledge in order to face with requirements of a global community effectively. Cultural intelligence is emerged as an important factor in effective performance and interaction inside and among various cultural environments. Present research aims to examine the relationship between cultural intelligence and Gainful employment. Needed data are gathered by a purposive sampling. The researcher has collected data of 80 sample in which 40 were from Government sector and 40 from private sector. Research also wanted to find out that who is more culturally intelligent and gainfully employed; government employees or private sector employees because working condition and type of work are totally different in there two sectors.

The data gathered by the questionnaire was analyzed by the use of descriptive statistics and correlations analyses. The analyses the statistical program SPSS was used in data analyses. Researcher used A paired-samples t-test was conducted to compare the CQ and the Gainful employment of the government and private sector employees and researcher also used A Pearson product-moment correlation coefficient to assess the relationship between the CQ and the Gainful employment.

Now results are discussed in two sections $A$ deals with the T test part and Section $B$ deals with correlation.

\section{Section A}

Present section will deal with the results of the $t$ test.

A paired-samples t-test was conducted to compare the CQ and the Gainful employment of the government and private sector employees. There was a significant difference in the scores for cultural intelligence in government employees and private sector employee.

Table 4.1 Showing the significant difference between the scores of government employees and private sector employees

\begin{tabular}{|c|c|c|c|c|c|c|c|c|}
\hline & Sector & $\mathbf{N}$ & Mean & $\begin{array}{l}\text { Std. } \\
\text { Deviation }\end{array}$ & $\begin{array}{l}\text { Std. } \\
\text { Error } \\
\text { Mean }\end{array}$ & $\mathbf{t}$ & $\begin{array}{l}\text { D } \\
\text { f }\end{array}$ & Sig. \\
\hline \multirow[t]{2}{*}{ CQ_S_ } & government & 40 & 20.5500 & 1.58438 & .25051 & \multirow[t]{2}{*}{-4.80} & \multirow[t]{2}{*}{78} & \multirow[t]{2}{*}{0.000} \\
\hline & private & 40 & 22.5250 & 2.06295 & .32618 & & & \\
\hline \multirow[t]{2}{*}{ CQ_K_ } & government & 40 & 13.3250 & 2.63495 & .41662 & \multirow[t]{2}{*}{-16.26} & \multirow[t]{2}{*}{78} & \multirow[t]{2}{*}{0.000} \\
\hline & private & 40 & 26.9000 & 4.57305 & .72306 & & & \\
\hline \multirow[t]{2}{*}{ CQ_M_ } & government & 40 & 14.0750 & 2.74924 & .43469 & \multirow[t]{2}{*}{-12.52} & \multirow[t]{2}{*}{78} & \multirow[t]{2}{*}{0.000} \\
\hline & private & 40 & 23.4750 & 3.86959 & .61184 & & & \\
\hline \multirow[t]{2}{*}{ CQ_B_ } & government & 40 & 16.7000 & 2.70043 & .42698 & \multirow[t]{2}{*}{-7.72} & \multirow[t]{2}{*}{78} & \multirow[t]{2}{*}{0.000} \\
\hline & private & 40 & 23.6500 & 5.01050 & .79223 & & & \\
\hline \multirow[t]{2}{*}{ GEmp_A_ } & government & 40 & 2.6678 & .36947 & .05842 & \multirow[t]{2}{*}{-2.96} & \multirow[t]{2}{*}{78} & \multirow[t]{2}{*}{0.004} \\
\hline & private & 40 & 2.8710 & .22573 & .03569 & & & \\
\hline
\end{tabular}




\section{Cultural Intelligence and Gainful Employment in Management}

This result suggests that private sector employees are more culturally intelligent in comparison to government employees also they are more gainfully employed. Results also indicate that private sector employees scored high in all the 4 dimension of CQ.

That means private sector employees are better in CQ strategy which means they are better in understanding others cultural preferences and while interacting they are able to understands the differences in the cultures. This can be because the private sector employees are getting opportunities to deal with the clients of different states. Also it can be because of the verities they are getting in their work.

Private sector employees also scored high in CQ cognition which means they are they are better in understanding the norms and interpersonal system of different culture. Also it means they are able to understand similarities and differences across culture. It also means that they are tend to take more risk in order to understand others culture and to adjust with the differences. Similar kind of results was found in the study conducted by the (Prado, 2006). In a study of 120 managers from 27 countries, Prado (2006) found that cognitive and meta cognitive CQ Positively predicted managers' perceived cross-border environment uncertainty, which has important implications for accurate risk assessment in international business ventures.

Private sector employees also scored high in CQ motivation and CQ behaviour which means that they are able to adjust in foreign environment easily and it also means that they are able to adjust in culturally demanding situation better and also that they are better in work interaction and general interaction and psychological adjustment. A number of studies have found that supports the results.. In a study of global professionals, Templer, Tay,and Chandrasekar (2006) demonstrated that motivational CQ predicted work and general adjustment over and above realistic job previews and realistic living conditions previews. Likewise, Ang et al. (2007) demonstrated in multiple studies that individuals with higher motivational and behavioral

CQ reported better general, work, interactional, and psychological adjustment. In a study of American expatriates in China, Williams (2008) found that cognitive CQ predicted socio cultural adjustment and motivational CQ predicted both socio cultural and psychological adjustment. In a very recent study involving multisource and multilevel data, Chen, Kirkman, Kim, Farh, and Tangirala (2010) showed that motivational CQ influenced work adjustment of expatriates and that the effect was stronger when cultural distance and subsidiary support were lower.

Results also shows that private sector employees are more gainfully employed in comparison to the government sector employees this can be because of the factor that private sector employees have varieties in their job and also they are able to maintain a friendly relationship as normally they work in tem unlike government sector. 


\section{Cultural Intelligence and Gainful Employment in Management}

Private sector employees consider them more gainfully employed may be because they feel safe in there working environment with all the new techniques which is still not there in government sector. It can also because they are able to earn a handsome amount of money. Private sector employees enjoy diversity in their work place which somehow gives then challenges and scope for improvement which is still not there in government sector.

\section{Section B}

Present section deals with the results of the correlation.

A Pearson product-moment correlation coefficient was computed to assess the relationship between the CQ and the Gainful employment. The results shows that the there is positive correlation between the gainful employment and CQ knowledge and CQ behavior in the government sector employees. Results also indicate that there is positive correlation between the gainful employment and CQ motivation and CQ behavior in the private sector employees.

Table 4.2 Showing the correlations between the CQ and GN-EM among the Government employees

\begin{tabular}{|c|c|c|c|c|c|c|}
\hline & & CQ_S_ & CQ_K_ & CQ_M_ & CQ_B_ & GEmp_A_ \\
\hline & Pearson & 1 & $2=\Gamma^{*}$ & 107 & & 201 \\
\hline & Correlation & & & & & \\
\hline CQ_S_G & Sig. (2-tailed) & & .024 & .303 & 697 & .213 \\
\hline & $\mathrm{N}$ & 40 & 40 & 40 & 40 & 40 \\
\hline & Pearson & & & & & \\
\hline & Correlation & & & & & \\
\hline CQ_K_G & Sig. (2-tailed) & .024 & & .255 & .567 & .384 \\
\hline & $\mathrm{N}$ & 40 & 40 & 40 & 40 & 40 \\
\hline & & .167 & .184 & 1 & -.076 & .261 \\
\hline & Sig. (2-tailed) & .303 & .255 & & .640 & .104 \\
\hline & $\mathrm{N}$ & 40 & 40 & 40 & 40 & 40 \\
\hline & Pearson & .064 & .093 & -.076 & 1 & -.052 \\
\hline
\end{tabular}

(C) The International Journal of Indian Psychology, ISSN 2348-5396 (e) | ISSN: 2349-3429 (p) | 117 
Cultural Intelligence and Gainful Employment in Management

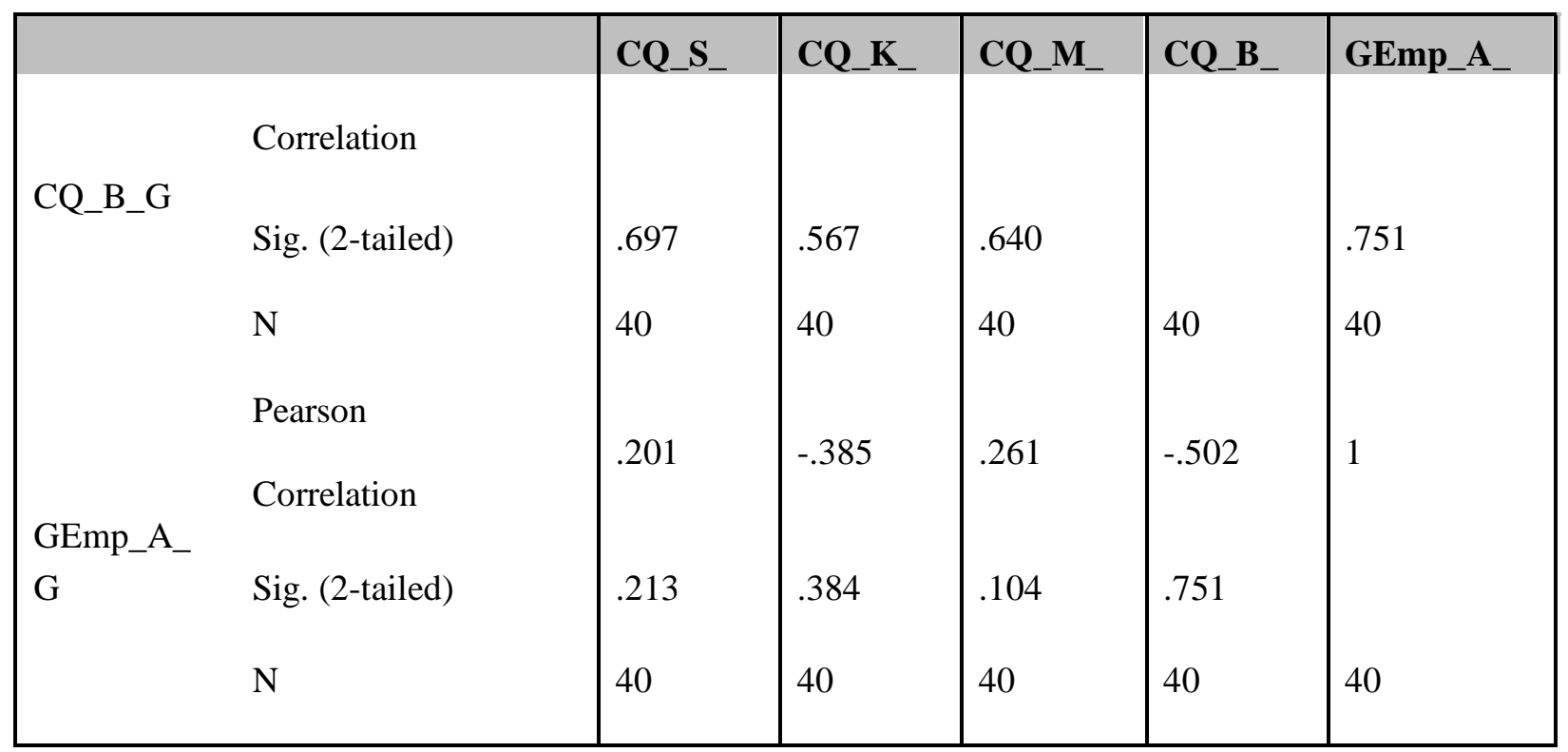

*. Correlation is significant at the 0.05 level (2-tailed).

Table 4.3 Showing the co relation between the CQ and GM-EM among the private sector employees

\begin{tabular}{|c|c|c|c|c|c|c|}
\hline & & cq_s & cq_k & cq_m & cq_b & ga_em \\
\hline \multirow{2}{*}{ CQ_S } & $\begin{array}{l}\text { Pearson } \\
\text { Correlation }\end{array}$ & 1 & .060 & .071 & .311 & -.097 \\
\hline & Sig. (2-tailed) & & .713 & .664 & .051 & .552 \\
\hline & $\mathrm{N}$ & 40 & 40 & 40 & 40 & 40 \\
\hline \multirow{4}{*}{ CQ_K } & $\begin{array}{l}\text { Pearson } \\
\text { Correlation }\end{array}$ & .060 & 1 & $.356^{*}$ & .146 & -.149 \\
\hline & Sig. (2-tailed) & .713 & & .024 & .368 & .358 \\
\hline & $\mathrm{N}$ & 40 & 40 & 40 & 40 & 40 \\
\hline & $\begin{array}{l}\text { Pearson } \\
\text { Correlation }\end{array}$ & .071 & $.356^{*}$ & 1 & $.391^{*}$ & -.083 \\
\hline \multirow[t]{2}{*}{ CQ_M } & Sig. (2-tailed) & .664 & .024 & & .013 & .612 \\
\hline & $\mathrm{N}$ & 40 & 40 & 40 & 40 & 40 \\
\hline
\end{tabular}

(C) The International Journal of Indian Psychology, ISSN 2348-5396 (e)| ISSN: 2349-3429 (p) | 118 


\section{Cultural Intelligence and Gainful Employment in Management}

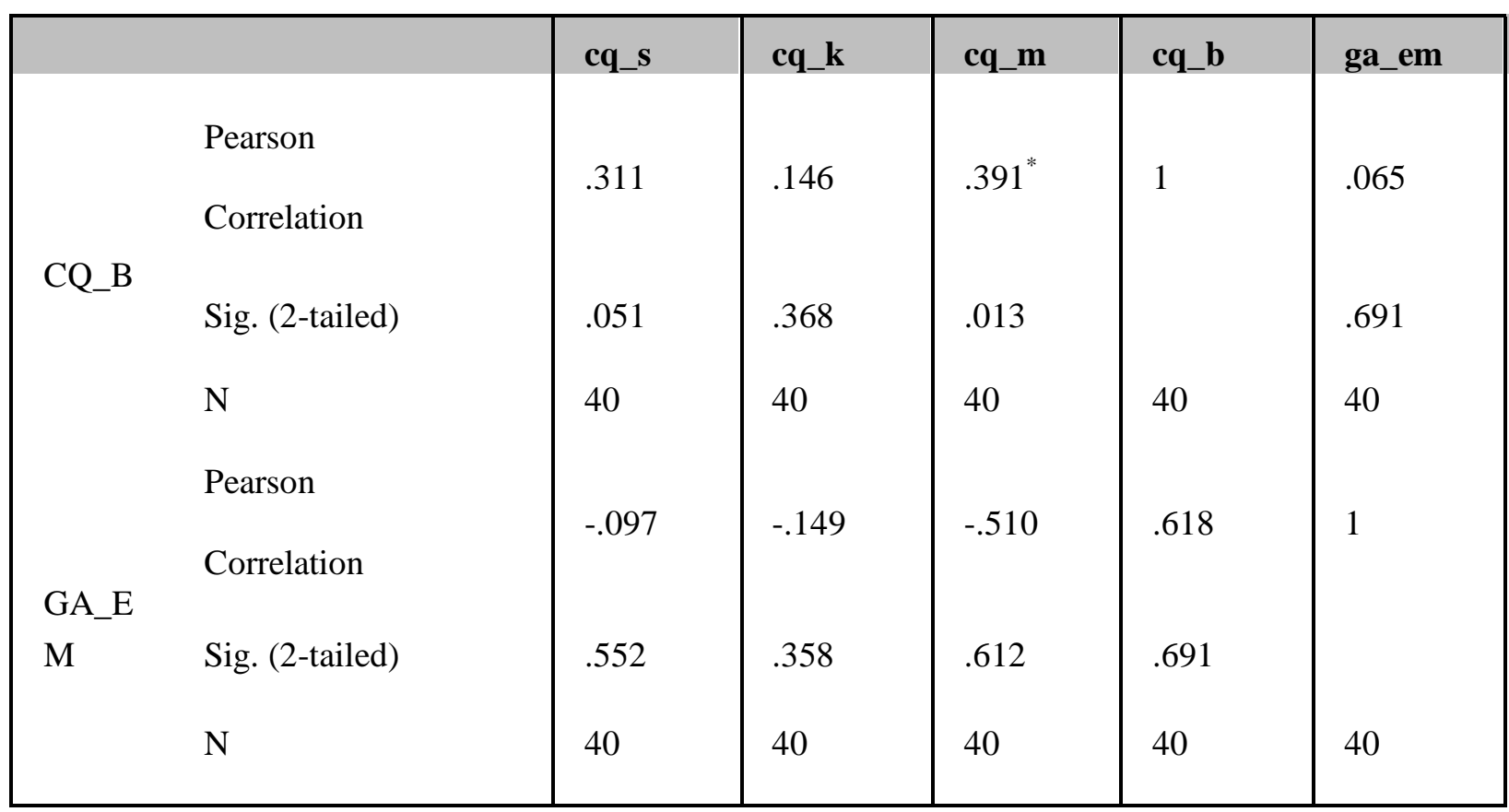

*. Correlation is significant at the 0.05 level (2-tailed).

There is a positive correlation between the gainful employment and CQ behavior in both government employees and private sector employees. This means that employees are capable of exhibit appropriate nonverbal and verbal actions when they are interacting with different culture. Also they are able behave according to the demand of the situation, such as appropriate words, gesture and facial expression.

There is high possibility according to the findings of the present research, that because of this quality of the employees they feel themselves gainful employees. Gainful employment is the perception of the employee that what makes him satisfied and happy in his job. There are chances that employees feel more satisfied with their job because they are able to behave in certain way with clients if different culture. There is a possibility that employees are able to perform verities of job because of their ability to perform things differently than others. Friendship at work place is not the problem for employees with high Behavior CQ because of their ability to ct according to the situation.

There is also possibility that employees how scored high on CQ behavior are able to do so because they are gainfully employed. Employees are able to exhibit appropriate nonverbal and verbal action when they are interacting with clients from different culture. It could be because they are happy and satisfied in their job. One of the possible reasons could be that they feel secure in their job and their ability to handle diversity provides verities in their job.

There is also positive correlation between the Gainful employment and CQ knowledge in government sector employees. Employees with high CQ knowledge also called as CQ cognition

(C) The International Journal of Indian Psychology, ISSN 2348-5396 (e)| ISSN: 2349-3429 (p) | 119 


\section{Cultural Intelligence and Gainful Employment in Management}

are able to understand norms and practices of different culture.

Employees with high Knowledge CQ are able to understand similarities and differences across cultures. This could be because it provides verities in their job. Other reason could be it provide them satisfaction and ability to deal with diversity without losing one's own individuality and inner peace. The ability to understand others culture norms and practices at times brings positive engagement and involvement in employees work life.

This results also suggest that there is possibility that employees were already gainfully employed that why they were able to understand different cultures. One of the possible reasons could be that if they were not satisfied and happy with their working condition they would never had took this extra burden of understanding other cultures and differences and similarities across cultures.

Results also indicate that there is positive correlation between Gainful employment and motivation CQ. Employees with high motivation CQ are able to direct their attention and energy towards learning about the functioning in culturally diverse situations.

This could be because they want to enjoy verities in their job also it could be possible that it provides them happiness and job satisfaction. Another reason could be that it help to handle diversity effectively and creates a friendly environment for them where they feel safe. There is also a possibility that it gives them positive engagement and involvement.

Present research was the attempt to find out the relationship between the CQ and gain employment. Results show that there is a positive correlation between the two.

The relationship between the gainful employment and CQ also suggest that intervention programme on CQ can help increasing gainful employment.

\section{CONCLUSION}

The present study was carried out to find out the relationship between the CQ and Gainful employment. The researcher has collected data of 80 sample in which 40 were from Government sector and 40 from private sector. Research also wanted to find out that who is more culturally intelligent and gainfully employed; government employees or private sector employees because working condition and type of work are totally different in there two sectors.

The data gathered by the questionnaire was analyzed by the use of descriptive statistics and correlations analyses. The analyses the statistical program SPSS was used in data analyses.

Researcher used A paired-samples t-test to compare the CQ and the Gainful employment of the government and private sector employees, and found out that there was a significant difference in the scores for cultural intelligence in government employees and private sector employees

(c) The International Journal of Indian Psychology, ISSN 2348-5396 (e)| ISSN: 2349-3429 (p) | 120 


\section{Cultural Intelligence and Gainful Employment in Management}

Also there was significant difference in the score for gainful employment in government and private sector

This result shows that Private sector employees have high CQ in comparison to government sector employees. Private sector employees cores high on all 4 domains of CQ that is CQ strategy, CQ knowledge, CQ motivation and CQ behaviour, also results shows that private sector employees are more gainfully employees or perceive themselves ore gainfully employed in comparison to government employees.

Researcher used A Pearson product-moment correlation coefficient to assess the relationship between the CQ and the Gainful employment and found out that there is a positive correlation between the gainful employment and CQ knowledge and CQ behavior in the government sector employees. Results also indicate that in private sector employees there is a positive correlation between the gainful employment and CQ motivation and CQ behavior.

\section{Limitations of the present research}

When a research is designed, all the possibilities are taken into consideration so that the research could attain the planned objectives successfully with minimum error and better applicability. All the efforts are made to make research plan full proof so that the intervening variable could be controlled. Still some limitations can be obtained in investigations. The present research has following limitations:

The present study is conducted on working population which limits its generalization on general population. Therefore, a representative random sample of the Indian working population needs to be surveyed.

The study is conducted on a sample of north India from small city; it is possible that if sample were collected from mix Indian sample or the sample belonging to other cultures and metropolitan city. The results differ in nature. Gender differences were not considered in the present study because of the limited numbers of organization for data collection. Not all the participants in the present study had the international experiences (especially government employees) that may have caused certain biases in the findings.

Gainful employment and cultural intelligence is relatively new construct in India. There is a great needing felt to operationalise and conceptualize the constructs like gainful employment and CQ in the Indian context with many more data based investigations.

\section{Suggestion for future research}

This study had many limitations; however this research done in this study sets the stage for future research which was intent.

(c) The International Journal of Indian Psychology, ISSN 2348-5396 (e)| ISSN: 2349-3429 (p) | 121 


\section{Cultural Intelligence and Gainful Employment in Management}

The findings that the present study suggests are that future research should look at the effects of gender. The study is conducted on a sample of north India from small city; for future research it would be interesting to use a mix Indian sample or the sample belonging to other cultures and metropolitan city.

Finding of the research shows that there is positive correlation between CQ and gainful employment. That gives the possibility to develop the intervention programme.

\section{Acknowledgments}

The author appreciates all those who participated in the study and helped to facilitate the research process.

Conflict of Interests: The author declared no conflict of interests.

\section{REFERENCES}

Ang, S. and Van Dyne, L. (2008). Handbook of cultural intelligence. Armonk, N.Y.: M.E. Sharpe.

Ang, S., Van Dyne, L., Koh, C., Ng, K., Templer, K., Tay, C. and Chandrasekar, N. (2007). Cultural Intelligence: Its Measurement and Effects on Cultural Judgment and Decision Making, Cultural Adaptation and Task Performance. Management Organization Review, 3(3), pp.335-371.

Cooke, W. (1994). Employee Participation Programs, Group-Based Incentives, and Company Performance: A Union-Nonunion Comparison. Industrial and Labor Relations Review, 47(4), p.594.

Elsaid, A. (2012). The Effects of Cross Cultural Work Force Diversity on Employee Performance in Egyptian Pharmaceutical Organizations. BMR, 1(4).

Groves, K. and Feyerherm, A. (2011). Leader Cultural Intelligence in Context: Testing the Moderating Effects of Team Cultural Diversity on Leader and Team Performance. Group \& Organization Management, 36(5), pp.535-566.

hlewind, Gainful employment and the inter-generational contract. Nurnberg, Germany: IAB.

Konanahalli, A., O. Oyedele, L., Spillane, J., Coates, R., von Meding, J. and Ebohon, J. (2014). Cross-cultural intelligence (CQ). International Journal of Managing Projects in Business, 7(3), pp.423-448.

Nafei, W. (2012). The Impact of Cultural Intelligence on Employee Job Performance: An Empirical Study on King Abdel-Aziz Hospital in Al-Taif Governorate, Kingdom of Saudi Arabia. IJBM, 8(1).

Nath, J. (2012). Cultural intelligence must for global leaders. [online] The Hindu. Available at: http://www.thehindu.com/todays-paper/tp-features/tp-opportunities/cultural-intelligencemust-for-global-leaders/article2809926.ece [Accessed 20 Apr. 2015]. 


\section{Cultural Intelligence and Gainful Employment in Management}

Ng, T., Sorensen, K. and Yim, F. (2009). Does the Job Satisfaction--Job Performance Relationship Vary Across Cultures. Journal of Cross-Cultural Psychology, 40(5), pp.761-796.

Şahin, F., Gurbuz, S. and Köksal, O. (2014). Cultural intelligence (CQ) in action: The effects of personality and international assignment on the development of CQ. International Journal of Intercultural Relations, 39, pp.152-163.

Shoots, Q. (1965). Gainful employment of Negro home economics graduates with implications for educational programs.

Snyder, C. and Lopez ,S.(2007).Positive psychology. Thousand Oaks [u.a.]: Sage.

Van Dyne, L., Ang, S., Ng, K., Rockstuhl, T., Tan, M. and Koh, C. (2012). Sub-Dimensions of the Four Factor Model of Cultural Intelligence: Expanding the Conceptualization and Measurement of Cultural Intelligence. Social and Personality Psychology Compass, 6(4), pp.295-313.

How to cite this article: Kewalramani S, Chaubey S (2017), Cultural Intelligence and Gainful Employment in Management, International Journal of Indian Psychology, Volume 4, Issue 2, No. 93, ISSN:2348-5396 (e), ISSN:2349-3429 (p), DIP:18.01.132/20170402, ISBN:978-1-36578193-3 